ks. Grzegorz Godawa

Uniwersytet Papieski Jana Pawła II w Krakowie

\title{
Integralna wizja człowieka jako fundament kultury i wychowania
}

Teraźniejszość w dużym stopniu określa kształt przyszłości, dlatego warto obecnym czasom poświęcić uwagę i refleksję. Jaka jest ta teraźniejszość? Pod każdym względem różnorodna. Jest w niej wiele powodów do satysfakcji, ale nie brak i obaw. Można je odnaleźć m.in. w szczególnych obszarach życia człowieka, jakimi są tworzona przez niego kultura i wychowanie. Marian Nowak zauważa: „Nie jest to czas metafizyki ani miłości do filozofii, lecz czas, w którym człowiek chętniej nastawia się na wydajność, na skuteczność w działaniu i na sukces, gdy bardziej wierzy technologii i nauce aniżeli własnej intuicji i dedukcji. Z taką sytuacją mamy do czynienia również w pedagogice"1.

Nastawienie na wymienione przez autora praktyczne cele powoduje, że obszary charakteryzujące się innym rodzajem efektywności są bagatelizowane. Wydaje się, że u źródła tego zjawiska tkwi nie tylko potrzeba skuteczności i osiągania empirycznie wymiernych efektów, ale przyjęcie specyficznej koncepcji człowieka. Niekiedy jest nią jedno z popularnych dzisiaj ujęć osoby ludzkiej w kontekście zredukowanym, pozbawionym istotnych wymiarów życia ludzkiego. $Z$ drugiej strony dostrzegalna jest potrzeba dowartościowania osoby ludzkiej i ukazania jej w perspektywie integralnego rozwoju, zarówno w kulturze, jak i w procesie wychowania.

Zagadnienie integralnego i zredukowanego ujęcia osoby ludzkiej stało się zasadniczym obszarem badań podjętych na rzecz tego artykułu. Dla

M. Nowak, Filozofia człowieka podstawa filozofii wychowania, [w:] Wychowanie personalistyczne. Wybór tekstów, red. F. Adamski, Kraków 2005, s. 133. 
zaprezentowania problematyki związanej z teraźniejszością i przyszłością rozwoju człowieka potrzebne jest przywołanie wybranych wątków $\mathrm{z}$ antycznych i średniowiecznych koncepcji osoby, pokazanie istoty i skutków błędu antropologicznego oraz zaprezentowanie integralnej pedagogiki personalistycznej jako drogi do przywrócenia osobie pełnego znaczenia i perspektyw rozwoju.

\section{W poszukiwaniu definicji osoby}

Koncepcja człowieka jest uwarunkowana założeniami poznawczymi dotyczącymi świata i człowieka. Współczesne rozumienie człowieka prezentowane w kulturze w dużym stopniu opiera się na dziedzictwie dwóch odmiennych sposobów postrzegania i opisywania rzeczywistości: platońskiej i arystotelesowskiej. Chociaż nie można wnioskować, iż współczesne prądy myślowe są prostym następstwem myśli starożytnych filozofów, jednak ich wpływ jest obserwowalny ${ }^{2}$. Wpłynęły one na założenia związane z wychowaniem i kulturą, dlatego warto ukazać ich zarys.

Platońska wizja człowieka, przejęta od pitagorejskiego nurtu religijnego, ujmuje człowieka jako „duch-rozum”, żyjący w kontekście bogów, wcielający się w różne ciała ludzkie i zwierzęce ${ }^{3}$. Skazany na wcielenie zostaje „uwięziony” w ciele. W dualistycznej interpretacji rzeczywistości człowiek jest istotą wewnętrznie rozdartą - na byt i niebyt, dobro i zło, duszę i ciało. W człowieku dominuje piętno przeznaczenia, nieszczęścia i bezsensu, co wyraża prawo konieczności ${ }^{4}$. Platoński obraz człowieka był modyfikowany w średniowieczu i nowożytności. Znalazł on odzwierciedlenie w akcentowaniu dualizmu ciała i duszy, absolutyzowaniu sfery poznawczej człowieka oraz redukowaniu uczuć i zmysłów do sfery irracjonalnej i autonomicznej, przy jednoczesnym deprecjonowaniu sfery cielesności ${ }^{5}$. W ciągu wieków takie pojmowanie człowieka doprowadziło do rozdzielenia rzeczywistości na materię i ducha, którym człowiek jest w pierwszym rzędzie. Sam w sobie doskonały, nie może podlegać wychowaniu, gdyż jest źródłem praw ${ }^{6}$.

2 Por. M. A. Krąpiec, Osoba ludzka i błędy w jej rozumieniu, [w:] Błąd antropologiczny, red. A. Maryniarczyk, K. Stępień, Lublin 2003, s. 35.

3 Por. M. A. Krąpiec, Osoba ludzka..., dz. cyt., s. 32n.

4 Por. Platon, Fajdros, [w:] Platon, Dialogi, tłum. W. Witwicki, Warszawa 2007, s. 37.

5 Por. A. Maryniarczyk, Koncepcja bytu a rozumienie człowieka, [w:] Błąd antropologiczny, dz. cyt., s. 93.

Por. M. A. Krąpiec, Człowiek bytem osobowym, [w:] Personalistyczna filozofia wychowania, red. F. Adamski, Kraków 1999, s. 81. 
Koncepcją zdecydowanie silniej związaną z materią był sposób postrzegania człowieka prezentowany przez Arystotelesa. Myśl ta zabezpieczała przed dualizmem ludzkiej natury, gdyż podkreślała, że człowiek w działaniu i poznaniu jest tożsamym bytem, w którym ciało i dusza mają się do siebie jak akt i możność . Odkrywając złożeniową strukturę bytu, Arystoteles wskazał na substancję, która stanowi o tożsamości zmiennego bytu. Przypadłości związane $\mathrm{z}$ materialną stroną bytu stanowią o treściowym bogactwie uposażenia konkretnego bytu ${ }^{8}$. Dusza człowieka, organizując ciało, posługuje się władzami. Człowiek, choć został uformowany na obraz zwierzęcia i zamieszkuje świat przyrody, dzięki rozumowi wyrasta ponad ten świat. Wychowanie w czystym ujęciu koncepcji Arystotelesa posiada wąski zakres oddziaływania.

Koncepcje Platona i Arystotelesa zostały zmodyfikowane i odczytane w nowych kontekstach, zwłaszcza związanych z objawieniem biblijnym. Wspólnym przekonaniem było odkrycie, że wyrażenie „osoba” oznacza najwyższą doskonałość substancji, co pozwala na szukanie w bycie osobowym czegoś, co najlepiej wyraża człowieka jako osobę . Neoplatonizm i tomizm określiły kształt pojmowania człowieka w kolejnych wiekach.

Jak zauważa Franciszek Adamski, św. Augustyn nadał wizji człowieka jednoznaczny wymiar personalistyczny. Augustyńska antropologia głosi, że ani ciało, ani dusza nie są pełnym człowiekiem, gdyż dopiero oba te elementy razem zespolone składają się na osobę ludzką. Ważnym dopowiedzeniem w tym względzie była klasyczna filozoficzna definicja osoby skonstruowana przez Boecjusza, która określa osobę mianem „indywidualnej substancji rozumnej natury”. Oznacza to, że „osobą jest jestestwo bytowo niepodzielne, posiadające atrybuty rozumu i woli, dzięki którym posiada świadomość swego psychicznego «ja»" ${ }^{\text {”o. }}$. Posługując się współczesnymi pojęciami, można przyjąć, że wychowanie zakorzenione w nurcie myśli św. Augustyna było realizowane w oparciu o umiarkowany pajdocentryzm, wyrażający się w stosowaniu pozytywnych bodźców pobudzających do samodzielności, uwzględnianiu potrzeb wychowanka i organizowaniu jego rozwoju $\mathrm{u}^{11}$.

7 Por. Arystoteles, O duszy, oprac. P. Siwek, Warszawa 1988, ks. II, rozdz. I, s. 73n.

8 Por. A. Maryniarczyk, Koncepcja bytu..., dz. cyt., s. 97.

9 Por. M. A. Krąpiec, Osoba ludzka..., dz. cyt., s. 36.

${ }^{10}$ F. Adamski, Pedagogika chrześcijańska pedagogika personalistyczna, „Paedagogia Christiana” 31 (2013) nr 1, s. 11on.

${ }_{11}$ Por. J. J. Pawłowicz, Implikacje moralne teologii wspólnoty małżeńsko-rodzinnej w nauczaniu Cerkwi prawosławnej i Kościoła rzymskokatolickiego. Studium porównawcze, Tuchów 2011, s. 135n. 
Dla św. Tomasza z Akwinu, który dokonał interpretacji poglądów Arystotelesa, człowiek jest jednością, całościowym bytem ${ }^{12}$. Nie jest więc mozaiką, zespołem różnych elementów, wielością, dwoistością duszy i ciała. Stanowi nierozerwalną całość, compositum humanum ${ }^{13}$. Integralność bytu ludzkiego, której bronił św. Tomasz, stała się podstawą do współczesnego holizmu, a w dalszej perspektywie personalizmu. Dla rozważań pedagogicznych można przyjąć, iż wszystkie władze duszy ludzkiej mają na celu udoskonalanie człowieka, a więc jego rozwój. Jak zauważa Akwinata: „w człowieku istnieje z natury jakaś podatność na cnotę. Ale sama podatność nie wystarcza jeszcze do osiągnięcia doskonałej cnoty. Musi jeszcze dojść jakaś praca wychowawcza ze strony człowieka"14. Perspektywa wychowawcza zarysowana w tomistycznej filozofii wychowania zgadza się z jego integralną antropologią i z koncepcją człowieka jako osoby. Ona najbardziej realizuje się poprzez asymilację wartości, zwłaszcza: prawdy, dobra, piękna i świętości ${ }^{15}$.

\section{Błąd antropologiczny i jego skutki w kulturze oraz wychowaniu}

Przełomowym okresem w dziejach rozwoju ludzkiej myśli było oświecenie. Przyczyniło się ono do rozwinięcia idei humanizmu, która zaczęła odgrywać ważną rolę już w renesansie, a w oświeceniu stała się prawie powszechnie obowiązująca. Osiemnastowieczna myśl oświeceniowa podkreśliła znaczenie ludzkiej natury, przez co w znacznym stopniu odeszła od perspektywy metafizycznej. Wizje człowieka prowadziły niekiedy do zredukowanego patrzenia na życie ludzkie, co wyrażało się w niektórych humanizmach oświeceniowych ${ }^{16}$. Na szczególną uwagę w perspektywie wychowawczej zasługuje humanizm Jana Jakuba Rousseau. Chociaż protestował on przeciwko niektórym ideom oświeceniowym, to jednak gloryfikując naturę, uczucia i wolność, inspirował

${ }_{12}$ Por. S. Swieżawski, Św. Tomasz na nowo odczytany, Kraków 1983, s. 118.

${ }_{13}$ Por. W. Cichosz, Koncepcja osoby ludzkiej w filozofi św. Tomasza z Akwinu, „Studia Gdańskie”, 13 (2000), s. 6.

${ }_{14}$ Św. Tomasz z Akwinu, Suma Teologiczna, t. 13, tłum. P. Bełch, Londyn 1986, s. 39.

${ }^{15}$ Por. H. Majkrzak, Filozofia wychowania w ujęciu św. Tomasza z Akwinu, „Człowiek w Kulturze” 17 (2005), s. 205.

16 Por. I. Dec, Humanizmy i ich roszczenia w wyjaśnianiu człowieka, [w:] Błąd antropologiczny, dz. cyt., s. 53 . 
współczesnych sobie i późniejszych naturalistów i humanistów ${ }^{17}$. Naturalizm pedagogiczny, reprezentowany przez Rousseau, wyrastał z wizji człowieka, która przez niektórych uznawana jest za utopijną, gdyż zasadza się na przekonaniu o naturalnej świętości natury ludzkiej oraz deprywacyjnym wpływie wychowania ${ }^{18}$.

We współczesnym świecie, począwszy od oświecenia, można dostrzec zjawisko koncentrowania się człowieka na samym sobie, a nie na Bogu czy universum. Przez to radykalnie oddala się wymiar stworzoności i bycia częścią wszechświata, a człowiek, wywyższając swoją godność, staje się konstruktorem swego przeznaczenia (homo faber, tzn. budowniczy, a nie tylko użytkownik tego świata). Ideologie obecne w społeczeństwach XIX i XX w. w dużym stopniu konstruowały życie społeczne, kulturalne, polityczne i indywidualne ${ }^{19}$.

Humanizmy powstałe w tym czasie ukazują człowieka jako centrum zainteresowań. Począwszy od heglowskiego potraktowania człowieka jako instrumentu Absolutu, a ducha człowieka jako ostatecznej zasady wszelkiego bytu, rozpoczyna się proces wzrastania samoświadomości człowieka przy jednoczesnym minimalizowaniu roli Boga ${ }^{20}$. Dwudziestowieczne humanizmy tworzą szeroki zbiór dorobku ludzkiej myśli, które za Ignacym Decem można sklasyfikować jako: humanizmy horyzontalne (ateistyczne), teistyczne (pozatomistyczne) oraz personalistyczno-tomistyczne ${ }^{21}$. Humanizm teistyczny, silnie zróżnicowany i reprezentowany przez liczne grono myślicieli, posiada charakter personalistyczny, gdyż prezentuje osobowy ludzki byt w różnych aspektach jego funkcjonowania, jednak nie uwydatnia tego, co wyróżnia człowieka w całej hierarchii bytów i stanowi proprium humanum ${ }^{22}$. Humanizm teistyczny zakłada, że człowiek nie jest osobą, lecz staje się nią w procesie personalizacji. Teza ta odwołuje się do ewolucjonizmu antropologicznego i niejako pozbawia człowieka autonomii bytowej ${ }^{23}$. Humanizm personalistyczny w ujęciu tomistycznym zostanie poddany analizie w dalszej części artykułu. W tym

${ }_{17}$ Por. H. Rotkiewicz, Jean-Jacques Rousseau a kategoria „innego”, „Przegląd Filozoficzny Nowa Seria" 21 (2012) nr 4, s. 158.

18 Por. H. Rotkiewicz, Jean-Jacques Rousseau..., dz. cyt., s. 159.

19 Por. M. Nowak, Filozofia człowieka..., dz. cyt., s. 147.

${ }^{20}$ Por. I. Dec, Humanizmy..., dz. cyt., s. 55n.

${ }^{21}$ Por. I. Dec, Humanizmy..., dz. cyt., s. 56.

${ }^{22}$ Por. I. Dec, Humanizmy..., dz. cyt., s. 66.

23 Por. B. Kiereś, Personalizm jako odpowiedź na antyedukację, „Człowiek w Kulturze” 25 (2015), s. 256 . 
miejscu niezbędne wydaje się zaprezentowanie ogólnych założeń humanizmu horyzontalnego.

Humanizm horyzontalny, reprezentowany przez Ludwiga Feuerbacha, Karola Marksa, Fryderyka Nietzschego czy Jeana-Paula Sartre’a, budował materialistyczną wizję człowieka, którego w środowisku przyrodniczym wyróżnia samoświadomość, praca, wolność i relacje społeczne. Głosząc „wyzwolenie” człowieka $\mathrm{z}$ sideł ideologii i religii, sam stawał się niepostrzeżenie podbudową totalitaryzmu. Pomijał duchowy wymiar ludzkiego życia związany z transcendencją człowieka nad zastanym światem, a ten jest wszak podstawą do wypracowania koncepcji człowieka jako osoby ${ }^{24}$. Oświeceniowe i współczesne koncepcje antropologiczne doprowadziły do zasadniczych zmian również w szeroko rozumianej kulturze. Zredukowana wizja człowieka, w której bagatelizuje się bądź usuwa wątek religii, doprowadziła do powstania scjentystycznej wizji kultury, akcentującej naukę, technikę i postęp $\mathrm{p}^{25}$.

Liberalizm i postmodernizm, które nie uznają istnienia obiektywnej prawdy, a w których dobro i zło są określane na zasadzie konwencji, w dużym stopniu kształtują współczesną kulturę. Odejście od obiektywnej prawdy i traktowanie jej jako zagrożenia wolności człowieka stworzyło model człowieka wyzwolonego od prawdy, moralności i religii. Kultura, coraz częściej wypełniona czynnikiem profanum, spycha czynnik sacrum na daleki margines lub zdecydowanie mu się przeciwstawia. „Wynika to - jak zauważa Adamski - z przyjętej wizji świata i człowieka, z oparcia na takiej wizji filozofii wychowania i całej konstrukcji społeczno-ustrojowej i kulturowo-moralnej państwa czy narodu bądź z praktycznego zmaterializowania życia”26.

Wojciech Chudy uzupełnia tę wypowiedź, podkreślając, że skutkiem błędu antropologicznego jest odebranie wolności w podejmowaniu decyzji, indoktrynacja, degradacja etosu zawodowego, narzucanie poprawności politycznej, deformacja kultury czy komercjalizacja demokracji ${ }^{27}$. Konsekwencje są widoczne także w sztuce, która bazuje na wiedzy artysty i jest wyrazem jego woli doskonalenia świata. Błąd poznawczy powoduje fałsz w wytworach artystycznych, objawiający się np. w rozbieżności teorii sztuki z prawdą o realnym świecie ${ }^{28}$.

${ }^{24}$ Por. B. Kiereś, Personalizm jako odpowiedź na antyedukację, dz. cyt., s. 255.

25 Por. F. Adamski, Kultura między sacrum i profanum, [w:] Człowiek, wychowanie, kultura. Wybór tekstów, red. F. Adamski, Kraków 1993, s. 198.

${ }^{26}$ F. Adamski, Posłowie, [w:] Wychowanie personalistyczne..., dz. cyt., s. $421 \mathrm{n}$.

27 Por. W. Chudy, Kłamstwo społeczne i jego skutki, [w:] Błąd antropologiczny, dz. cyt., s. 212-218.

${ }_{28}$ Por. H. Kiereś, Błąd antropologiczny w sztuce, [w:] Błąd antropologiczny, dz. cyt., s. 297. 
Błąd antropologiczny wywołuje szczególne reperkusje w obszarze wychowania. Humanizm horyzontalny stał się fundamentem rozwoju teorii wychowania, która wyrasta z założeń pajdocentrycznych. Pajdocentryzm, obok szlachetnych idei, zawierał także wiele szkodliwych elementów, zwłaszcza ideę niczym niekrępowanej indywidualności dziecka ${ }^{29}$. Idea skupienia uwagi na dziecku skonfrontowana $\mathrm{z}$ horyzontalnym ujęciem ludzkiej egzystencji zaowocowała powstaniem paradygmatu pedagogicznego określanego jako pajdocentryzm humanistyczny. Paradygmat ten określa „zespół przesłanek nadających indywidualistyczne i subiektywistyczne znaczenie faktom występującym w życiu społecznym [...]. Jest to jednocześnie paradygmat nastawiony na badanie konfliktów społecznych, paradygmat krytyczny wobec każdej formy dominacji nad indywidualnością jednostki”30. W świetle tych założeń każda ingerencja wychowawcza, zwłaszcza związana z działaniem systemowym, ogranicza lub wręcz zamyka możliwości rozwoju dziecka. Wyrazem sprzeciwu wobec tej ingerencji jest pedagogika antyautorytarna, emancypacyjna, międzykulturowa czy negatywna $a^{31}$.

Jeden z czołowych przedstawicieli antypedagogiki twierdzi, że wolność to ,absolutna zdolność człowieka. Każdy od chwili narodzin dysponuje zdolnością do samodzielnego podejmowania decyzji. Istnieje ona niezależnie od zgody lub zakazu innych ludzi, tak jak ręce, oddychanie, jedzenie czy picie. Dorośli nie muszą nic robić, aby dzieci mogły decydować o sobie. One to robią od chwili narodzin"32.

Zgoda na absolutną wolność dziecka i przyjęcie zasady nieingerowania w jego rozwój to przejawy skrajnego liberalizmu w pedagogice. Niemniej te założenia są realizowane $\mathrm{w}$ wychowaniu, a ich skutki są coraz częściej dostrzegane. Wystarczy nawiązać do koncepcji tzw. wychowania bezstresowego prowadzącej niekiedy do pajdokracji33. Poszukiwanie usprawiedliwienia tej idei w antycznych koncepcjach wychowawczych wydaje się nadużyciem. Dla Sokratesa wolność wychowanka nie ma charakteru absolutystycznego, ale

${ }^{29}$ Por. J. Wilk, Wychowawca wobec pytania: „Kim jest dziecko”, [w:] Oblicza dzieciństwa, red. D. Kornas-Biela, Lublin 2001, s. 189.

${ }^{30}$ K. Rubacha, Budowanie teorii pedagogicznych, [w:] Pedagogika. Podręcznik akademicki, t. 1, red. Z. Kwieciński, B. Śliwerski, Warszawa 2008, s. 61 .

${ }^{31}$ Por. K. Rubacha, Budowanie teorii pedagogicznych, dz. cyt., s. 63.

${ }^{32}$ H. von Schoenebeck, Antypedagogika. Być i wspierać zamiast wychowywać, tłum. N. Szymańska, Warszawa 2007, s. 126.

33 Por. G. Godawa, Szkoła skoncentrowana na uczniu a afirmacja pajdokracji, [w:] Szkoła i jej etyczne wyzwania, red. J. Siewiora, Tarnów 2015, s. 43-47. 
polega na umiejętności panowania nad samym sobą (gr. enkrateia) ${ }^{34}$. Z kolei Platon uważał, że celem wychowania jest doprowadzenie do harmonii między rozumną częścią człowieka a szlachetniejszymi spośród irracjonalnych popędów duszy, dzięki czemu są one opanowane ${ }^{35}$.

Brak integralnego spojrzenia na człowieka ogranicza jego rozwój, gdyż ideologia ponowoczesności stwarza możliwości rozwoju, które obiektywnie są utopią, ale subiektywnie są tym bardziej atrakcyjne i pociągające. Pośród nich znajdują się takie, które są oparte na behawioralnej koncepcji człowieka, eliminacji z kultury i wychowania profilu chrześcijańskiego, radykalnym naturalizmie i supremacji idei liberalnych ${ }^{36}$. Najbardziej szkodliwa w wymiarze pedagogicznym jest obietnica łatwego szczęścia, osiągniętego inaczej niż poprzez wychowanie do dojrzałej miłości ${ }^{37}$.

Ciekawą interpretację kryzysu współczesnej pedagogiki podaje Piotr Tomasik, który odwołując się do spostrzeżeń wielu autorów, pisze:

Założenie Arystotelesa, iż charakter jest nabywany, pozwala wiązać wychowanie z powtarzaniem czynów cnotliwych, natomiast założenie Schopenhauera o niezmienności charakteru prowadzi do stwierdzenia, że wychowanie jest niemożliwe. Podobnie, jak twierdzi W. Chudy, przyjęcie na gruncie antropologii liberalnej zasady uzgadniania zakresów wolności wychowawcy i wychowanka w formie walki lub kompromisu prowadzi do współczesnego kryzysu szkoły, który przejawia się rezygnacją ze wspólnej drogi ku prawdzie. Właśnie koncepcja pedagogiczna J. Deweya zawierała założenie, że istoty ludzkie są integralną częścią natury, co prowadziło do wniosku, iż, jak to ujmuje L. Chmaj, poznanie przestaje mieć charakter poszukiwania prawdy; zwrócone ku potrzebom życia ma ono ułatwić człowiekowi przystosowanie się do zmiennej rzeczywistości. Pedagogika postmodernistyczna opiera się z kolei na deklarowanym braku antropologii, co zresztą też jest antropologią ${ }^{38}$.

${ }^{34}$ Por. W. Jaeger, Paideia. Formowanie człowieka greckiego, tłum. M. Plezia, H. Bednarek, Warszawa 2001, s. 607.

35 Por. W. Jaeger, Paideia..., dz. cyt., s. 942.

${ }^{36}$ Por. A. Rynio, Wychowanie integralne w myśli Jana Pawła II, Lublin 2004, s. 334n.

37 Por. M. Dziewiecki, Wychowanie $w$ dobie ponowoczesności, Kielce 2002, s. 29.

${ }^{8}$ P. Tomasik, Pedagogika wobec kryzysu wychowania, „Warszawskie Studia Teologiczne” 11 (1998), s. 298. 
Powyższe słowa pokazują, że kryzys wywołany przyjęciem błędnej, bo niezgodnej z rzeczywistością koncepcji osoby wywołuje reperkusje, które są odczuwane w dzisiejszej praktyce wychowawczej. Nie mniej oddziałują na kulturę, która podporządkowując się współczesnym trendom, niejednokrotnie zatraca pełnię oglądu osoby ludzkiej. Przeciwwagę dla tych redukcjonistycznych trendów stanowi humanizm personalistyczny.

\section{Personalistyczna koncepcja człowieka}

Personalizm posiada wiele odmian ${ }^{39}$ wynikających z nieco odmiennych interpretacji jego podstawowych założeń, lecz do ich wspólnych cech zaliczyć można: opowiedzenie się za autonomią osób, ich godnością oraz zdolnością do wykraczania poza naturę i historię ${ }^{40}$. Termin ten nawiązuje do greckiego słowa prosopon (osoba) i jest odnoszony do wszystkich nurtów i teorii, które eksponują osobę jako istotę autonomiczną, posiadającą godność i rozum. Podkreślić należy, iż niezbędne jest odróżnienie personalizmu jako postawy interpersonalnej, wyrażającej się w szacunku i uznaniu praw drugiej osoby, od personalizmu filozoficznego, dla którego pojęciem podstawowym jest pojęcie osoby ludzkiej" ${ }^{41}$.

Personalizm jest ontologiczno-aksjologiczną koncepcją człowieka jako osoby, która stanowi byt w sobie i dla siebie. Będąc częścią świata materialnego, przerasta go swym nadprzyrodzonym odniesieniem. Osoba jest obdarzona należnymi jej prawami i jako taka stanowi cząstkę składową rodziny i innych społeczności ${ }^{42}$.

Personalizm chrześcijański jest zbudowany na bazie metafizyki chrześcijańskiej i antropologii św. Tomasza z Akwinu, odwołuje się do boecjańskiej definicji osoby, będącej jednostkową substancją natury rozumnej. Humanizm personalistyczny wyrasta z biblijnej wizji człowieka, zawierającej opisy stworzenia człowieka i dzieje upadku moralnego, a także z obrazu człowieka

39 Por. J. Lorenc, Wychowanie człowieka w ujęciu pedagogiki personalistycznej, „Zeszyty Naukowe Wyższej Szkoły Humanitas” 10 (2015), s. 16n.

40 Por. M. Wysocka, Personalizm, „Studia nad Rodziną” 10 (2006), s. 291.

${ }^{41}$ Por. B. Śliwerski, Pedagogika ogólna. Podstawowe prawidłowości, Kraków 2012, s. 271.

${ }^{42}$ Por. F. Adamski, Personalizm i pedagogika personalistyczna, [w:] Encyklopedia pedagogiczna XXI wieku, t. 4, red. T. Pilch, Warszawa 2005, s. 349. 
w pełni odkupionego w Jezusie Chrystusie ${ }^{43}$. Humanizm ten stanowi podstawę do opisania koncepcji pedagogiki personalistycznej.

\section{Pedagogika personalistyczna i jej integralny charakter}

Pedagogika personalistyczna zakłada, że człowiek jest osobą, co Wincenty Granat ujmuje w słowach: „Osoba ludzka to jednostkowy, indywidualny, substancjalny, cielesno-duchowy podmiot zdolny działać w sposób rozumny, dobrowolny, moralny i społeczny, w celu harmonijnego ubogacania siebie i innych ludzi w zakresie kultury" ${ }^{44}$. Człowiek nie jest więc zredukowany do kontekstu światopoglądowego czy ideologicznego, bo te deprecjonują jego osobę. Wolność i godność człowieka są wartościami, które wyrastają z usytuowania osoby ludzkiej w centrum zainteresowania. Miejscem wychowania jest spotkanie osób: mistrza i ucznia. Dlatego wychowanie nie może ograniczać się do teoretycznego przekazu wiedzy, ale powinno stać się wydarzeniem spotkania. Dokonuje się ono w perspektywie społecznej i jest uwarunkowane doświadczeniem historycznym ${ }^{45}$.

Celem działalności wychowawczej jest uzdolnienie wychowanka do przejęcia i kierowania własnym procesem wychowania, a jednocześnie jest ona skierowana na rzecz rozwoju osoby i wspólnoty. Wychowanie jest więc rozumiane jako proces rozwoju osobowego. W relacji wychowawczej między wychowawcą i wychowankiem podkreśla się wzajemność i podmiotowość wszelkich oddziaływań ${ }^{46}$.

Jak zauważa Alina Rynio, w pedagogice personalistycznej jest ważne „doświadczenie osobistego spotkania z obecnością Boga, dialog, wolne przylgnięcie do Chrystusa obecnego we wspólnocie wierzących; rozbudzenie pasji wobec prawdy samego siebie, szacunek wobec świata ludzi i rzeczy, przyjaźn połączona z możliwością korekty, posłuszeństwo i zdrowo pojęta zależność od autorytetu" ${ }^{47}$. Można więc przyjąć, iż pedagogika personalistyczna jest ukierunkowana na doskonalenie się człowieka w jego istnieniu, czyli zwró-

43 Por. K. Parzych-Blakiewicz, Personalistyczne podstawy humanizmu chrześcijańskiego. Zarys problematyki, „Teologia w Polsce” 5 (2011) nr 2, s. 300.

${ }^{44}$ W. Granat, Personalizm chrześcijański, Poznań 1985, s. 69 n.

45 Por. K. Kaczmarek, T. Gadacz, Racje za personalistyczna filozofia wychowania, [w:] Wychowanie personalistyczne..., dz. cyt., s. 175-177.

${ }^{46}$ Por. J. Lorenc, Wychowanie człowieka..., dz. cyt., s. 18.

47 A. Rynio, Atrakcyjność wychowania chrześcijańskiego, [w:] Wychowanie chrześcijańskie. Między tradycją a współczesnością, red. A. Rynio, Lublin 2007, s. 673. 
ceniu się ku dobru i osiąganiu coraz wyższego stopnia uczestniczenia w nim. Dążenie do doskonałości jest obowiązkiem moralnym, który wynika z istoty bycia człowiekiem.

O ile pedagogika humanistyczna, zbudowana na założeniach humanizmu horyzontalnego, ma wyłącznie antropocentryczny charakter, nurt personalistyczny proponuje drogę wychowania zakładającą istnienie znacznie szerszej perspektywy życia człowieka. W tym kontekście Bogusław Śliwerski zauważa:

Z personalistycznego spojrzenia na człowieka w procesie socjalizacji i wychowania wynikają: jego afirmacja jako wartości podstawowej i autotelicznej, prymat życia duchowego, nieredukowalność osoby do rzeczy, ciała, zmysłów i potrzeb biologicznych, niezbywalność praw tkwiących w naturze ludzkiej, świadomość powinności wobec innych opartej na zasadach sprawiedliwości oraz odrzucenie anarchicznej koncepcji wolności osoby ${ }^{48}$.

Takie założenia sugerują, że zakres zainteresowań pedagogiki personalistycznej znacznie wykracza poza wszelkie umniejszające godność koncepcje wychowania, tak jak filozofia personalistyczna rozszerza rozumienie człowieka poza ujęcia materialistyczne. Jedną $z$ cech wychowania stawiającego osobę ludzką w centrum zainteresowania jest integralność.

Adamski wymienia integralność jako istotną cechę osoby, sytuując ją obok duchowości i nieśmiertelności ${ }^{49}$. Autor wyprowadza integralność osoby z faktu, że „człowiek jest całością, a nie częścią czegoś - i jest całością spójną, kompletną: a jeśli tak, to od siebie samego otrzymuje zadania, obowiązki i uprawnienia, przede wszystkim zaś wartość najwyższą w świecie bytów stworzonych i wolność" ${ }^{\circ}$. Takie spojrzenie na osobę określa specyfikę wychowania integralnego. Jest ono odpowiedzią na potrzeby dynamicznie zmieniającej się rzeczywistości, która domaga się nieustającego rozwoju człowieka.

W tym kontekście Adamski stawia istotne pytanie: „Na ile jest się osobą, a staje się osobowością?" ${ }^{1}$. Odpowiadając na nie, należy podkreślić, iż osoba ludzka zawsze chce być sobą, choć nigdy nie jest w pełni zaktualizowana w tym pragnieniu. To mozolne osiąganie pełni siebie jest procesem, w którym biorą udział instytucje kształcenia i wychowania. Fundamentalnym założeniem

\footnotetext{
${ }^{48}$ B. Śliwerski, Pedagogika ogólna..., dz. cyt., s. 273.

49 Por. F. Adamski, Pedagogika chrześcijańska..., dz. cyt., s. 112.

${ }^{50}$ F. Adamski, Pedagogika chrześcijańska..., dz. cyt., s. 112.

${ }^{51}$ F. Adamski, Pedagogika chrześcijańska..., dz. cyt., s. 352.
} 
jest ukierunkowanie tego procesu rozwojowego na osiągnięcie prawdziwej wolności i uchronienie wychowanka przed pseudowartościami ${ }^{52}$.

Docelowym etapem wychowania personalistycznego jest osiągnięcie poziomu samowychowania, które polega na maieutyce osoby, czyli wzbudzeniu jej w wychowanku. Samodzielność stanowi jedną z istotnych cech samowychowania. Wychowanek jest pierwszym faktorem procesu wychowania, a wychowawca pełni jedynie rolę kooperatora. Stworzenie warunków, by wychowanek mógł sam pokierować swoim rozwojem, oraz uzdolnienie go do tego stanowi ważne zadanie wychowawcze ${ }^{53}$.

$\mathrm{Na}$ tych założeniach bazuje pedagogika integralna, która według Marka Dziewieckiego jest realistycznym i całościowym rozumieniem człowieka. Autor stawia słuszną diagnozę przyczyn niezadowalającej kondycji współczesnego wychowania:

Na początku xxI wieku niewielu wychowawców rozumie wychowanka zarówno w jego wielkości, jak też w jego ograniczeniach i słabościach. Modny jest bowiem obecnie optymistyczny humanizm, który bezkrytycznie powiela znane od dawna mity o spontanicznej samorealizacji, o wychowaniu bezstresowym [...]. W konsekwencji dominujące obecnie systemy pedagogiczne opierają się na zawężonej i naiwnej wizji wychowanka, redukując jego rzeczywistość do ciała, emocji i subiektywnych przekonań ${ }^{54}$.

Chcąc przeciwdziałać tym tendencjom, autor proponuje praktyczne spojrzenie na całościowy rozwój człowieka, obejmujące uznanie jego godności, pedagogię ciała, seksualności, myślenia, emocji, wolności, moralności, duchowości, religijności, powołania i dorastania do małżeństwa i rodziny ${ }^{55}$. Praktyczna realizacja tych wymiarów pedagogiki może wzmocnić całościowe spojrzenie na człowieka.

W nurcie pedagogiki personalistycznej szczególne miejsce zajmuje Karol Wojtyła, późniejszy papież. Proponowane przez niego założenia dotyczące wychowania stanowią ważny przyczynek do uczynienia tego procesu bardziej osobowym i integralnym.

\footnotetext{
${ }^{52}$ Por. F. Adamski, Pedagogika chrześcijańska..., dz. cyt., s. 352.

53 Por. R. Czekalski, Personalistyczne podstawy wychowania, Warszawa 2009, s. 36.

${ }^{54}$ M. Dziewiecki, Pedagogika integralna, Warszawa 2010, s. 8.

55 Por. M. Dziewiecki, Pedagogika integralna, dz. cyt.
} 


\section{Integralne wychowanie według Jana Pawła II}

Jan Paweł II podczas piątej pielgrzymki do Polski, przemawiając na Uniwersytecie Jagiellońskim w Krakowie, powiedział:

Innym warunkiem zdrowego rozwoju nauki, na który chciałem zwrócić uwagę, jest integralna koncepcja osoby ludzkiej. Wielki spór o człowieka u nas w Polsce wcale się nie zakończył wraz z upadkiem ideologii marksistowskiej. Spór o człowieka trwa w dalszym ciągu, a pod pewnym względem się nasilił. Formy degradacji osoby ludzkiej oraz wartości życia ludzkiego stały się bardziej subtelne, a tym samym bardziej niebezpieczne ${ }^{56}$.

Zwrócenie uwagi na znaczenie właściwego ujęcia osoby w kontekście redukcjonistycznych zagrożeń odnosi się nie tylko do rozwoju nauki, ale także do każdego obszaru ludzkiej działalności, w tym do wychowania. W nauczaniu Jana Pawła II jest ono osadzone w założeniach filozofii podkreślającej godność osoby. Karol Wojtyła, dostrzegając różnorodność ujęć personalistycznych, dążył do odnalezienia personalizmu uniwersalistycznego. Akcentował mistyczno-religijne ujęcie fenomenu osoby ludzkiej, a centralnym punktem jego koncepcji jest osoba, z pełną bytowością i realnością. Osoba jest także relacją do innych osób i do Boga. Wymiar religijny rozwoju człowieka jest wyrazem rozwoju bytu w wolności i miłości, a także poszukiwaniem doskonałości moralnej ${ }^{57}$.

W twórczości Karola Wojtyły - Jana Pawła II nie ma traktatów pedagogicznych w sensie ścisłym. Nie brak jednak wypowiedzi, które bezpośrednio odnoszą się do godności osoby ludzkiej oraz jej rozwoju, dlatego zasadne jest uwzględnienie implikacji wynikających $\mathrm{z}$ jego nauczania ${ }^{58}$. Jedną $\mathrm{z}$ istotnych cech pedagogiki w ujęciu papieża-personalisty jest integralność, która wyraża się w całościowym widzeniu człowieka oraz jego życia i zmierza do budowania krytycznej i systematycznej świadomości całej rzeczywistości ${ }^{59}$.

Pedagogika w ujęciu Jana Pawła ı nawiązuje do antropologii, określanej jako „antropologia adekwatna”. Stara się ona rozumieć i opisywać człowieka w tym,

${ }^{56}$ Piąta pielgrzymka Jana Pawła II do Ojczyzny, oprac. J. Górny, Olsztyn 1997, s. 162.

57 Por. M. Wysocka, Personalizm..., dz. cyt., s. 302.

${ }_{58}$ Por. J. Mastalski, Zarys teorii wychowania, Kraków 2002, s. 125 n.

59 Por. R. Czekalski, Personalistyczna pedagogika wychowawcza Jana Pawła II, „Warszawskie Studia Teologiczne” 21 (2008), s. 188. 
co istotowo ludzkie, nazywając go jego własnym imieniem ${ }^{60}$. Antropologia ta jest oparta na prawdzie o człowieku i otaczającym go świecie, która przyczynia się do jego wyzwolenia. Papieskie rozumienie wychowania dostrzega w prawdzie źródło bycia wychowywanym. Pedagogika wywodząca się z antropologii adekwatnej jest więc w dużym stopniu tożsama $\mathrm{z}$ pedagogiką integralną.

Pedagogika Jana Pawła II rozwinęła się na kilku płaszczyznach: osobowej, moralno-społecznej, kulturowo-aksjologicznej oraz wychowania w relacji do Boga ${ }^{61}$. Dla papieża autentyczne wychowanie jest wychowaniem integralnym, zarówno w strukturze, jak i w treści. Uznanie integralności bytu ludzkiego, jego cielesności i duchowości, które są nieredukowalne, stanowi fundament wychowania $^{62}$.

Na moralno-społecznej płaszczyźnie wychowania można wyróżnić kilka filarów, na których jest ono oparte. Należą do nich: prawda, sprawiedliwość, miłość, uczestnictwo i wolność. Na ich podstawie papież kształtuje odniesienie do świata i życia społecznego, właściwe dla autentycznego wychowania ${ }^{63}$. Kulturowo-aksjologiczna płaszczyzna wychowania integralnego odnosi się do uwarunkowań, w jakich się dokonuje. Karol Wojtyła, współtworzący współczesną sobie kulturę, podkreślał, że „wychowanie to twórczość o przedmiocie najbardziej osobowym" ${ }^{\prime 4}$. Owa twórczość posiada silne odniesienie aksjologiczne, gdyż wartości warunkują autentyczny rozwój ludzkiej myśli i wytworów. Chodzi więc o budowanie kultury wewnętrznej wychowanka, a także o kulturę człowieka i o kulturę obiektywną ${ }^{65}$. Dla Jana Pawła II kultura jest wyrazem i potwierdzeniem człowieczeństwa:

Kultura jest właściwym sposobem „istnienia” i „bytowania” człowieka. [...] jest tym, przez co człowiek jako człowiek staje się bardziej człowiekiem: bardziej „jest”. [...] Wszystko, co człowiek „ma”, o tyle jest ważne dla kultury, o tyle jest kulturotwórcze, o ile człowiek poprzez to, co posiada, może równocześnie pełniej

${ }^{60}$ Por. J. Galarowicz, Człowiek jest osoba. Podstawy antropologii filozoficznej Karola Wojtyły, Kraków 1994, s. 19.

${ }^{61}$ Por. A. Rynio, Wychowanie integralne..., dz. cyt., s. 103-179.

${ }^{62}$ Por. A. Rynio, Wychowanie integralne..., dz. cyt., s. 111.

${ }^{63}$ Por. M. Włosiński, Etyczne i pedagogiczne wartości przesłania Jana Pawła II - papieża nadziei, „Rocznik Naukowy Kujawsko-Pomorskiej Szkoły Wyższej w Bydgoszczy” 4 (2009), s. 237.

${ }^{64}$ K. Wojtyła, Miłość i odpowiedzialność, Lublin 1986, s. 54.

${ }_{5}$ Por. K. Chałas, Wychowanie w ujęciu Jana Pawła II inspiracją do budowania programu wychowawczego reformującej się szkoły, [w:] Wychowanie ku wartościom w świetle nauczania Jana Pawła II. Elementy teorii i praktyki, t. 3, red. K. Chałas, Lublin-Kielce 2006, s. 91. 
„być” jako człowiek, pełniej stawać się człowiekiem we wszystkich właściwych dla człowieczeństwa wymiarach swego bytowania ${ }^{66}$.

Papież przywiązywał dużą wagę do kształtowania kultury, a ponieważ wychowanie jest jej istotnym elementem, przypisywał mu ważną rolę. Kształtowanie właściwych postaw wobec wartości oraz wytworów ludzkich jest możliwe jedynie przy współudziale wychowania.

Teologiczne odniesienie wychowania integralnego pozwala dopełnić całościowy obraz człowieka i opisać jego rozwój. Człowiek stworzony na obraz Boga potrafi przekraczać samego siebie i otaczający go świat ${ }^{67}$. W tym kontekście znaczenia nabiera postulat samowychowania, prowadzącego do świętości. Alina Rynio zauważa, że integralność pedagogicznego przesłania Jana Pawła II wyraża się przede wszystkim w „całościowym widzeniu człowieka i w zdolnej do zaofiarowania wszystkiego - kulturze miłości”68.

Ta kultura jest antidotum na współczesne zagubienie w antropologii i filozofii człowieka, a co za tym idzie, także w kulturze i wychowaniu. Papież podkreśla, że błąd antropologiczny polega m.in. na odrzuceniu nadprzyrodzonej relacji Bóg-człowiek-przyroda. Przeakcentowanie ludzkiej roli powoduje, że godność ludzka - nawet uznawana i proklamowana - traci swoją najistotniejszą gwarancję, ponieważ „negacja Boga pozbawia osobę jej fundamentu, a w konsekwencji prowadzi do takiego ukształtowania porządku społecznego, w którym ignorowana jest godność i odpowiedzialność osoby"69. Czysto antropocentryczne ukierunkowanie myślenia i działania człowieka koncentruje jego aktywność na zapewnieniu dobra przede wszystkim samemu sobie.

Nazywając po imieniu współczesne deformacje prawdy, papież odwołuje się do integralnego ujmowania doświadczenia, tradycji, kultury i cywilizacji. Istotnym rysem tego ujęcia jest „dojrzały humanizm i personalizm połączony z otwarciem się na transcendentny sens ludzkiego życia. W ten sposób daje ona podstawy zarówno teologii, jak i filozofii wychowania. Zmusza też do zadumy

${ }^{66}$ Jan Paweł II, Przemówienie wygłoszone w siedzibie UNEsCo, Paryż, 2.06.198o, [w:] Jan Paweł II, Wiara i kultura. Dokumenty, przemówienia, homilie, Rzym-Lublin 1988, s. 55.

${ }^{67}$ Por. A. Rynio, Wychowanie w ujęciu Jana Pawła II. Wybrane zagadnienia teoretyczne, [w:] Wychowanie ku wartościom..., dz. cyt., s. 32.

${ }_{68}$ A. Rynio, Wychowanie w ujęciu Jana Pawła II..., dz. cyt., s. 35.

${ }^{69}$ Jan Paweł II, enc. Centesimus annus do czcigodnych braci w episkopacie, do kapłanów i rodzin zakonnych, do wiernych Kościoła Katolickiego i wszystkich ludzi dobrej woli w setną rocznicę encykliki Rerum novarum, 1.05.1991, Wrocław 2000, nr 13. 
i refleksji nad samym człowiekiem, jego sensem i fenomenem wychowania"7o. To i wcześniej ujęte zadania pozwalają na zaproponowanie implikacji, których realizacja może przyczynić się do wzmocnienia idei integralnego rozwoju człowieka.

\section{Implikacje dla rozwoju kultury i praktyki wychowawczej}

Spośród możliwych do wyodrębnienia implikacji wybrano kilka, które odnoszą się do kultury i wychowania:

\section{Przywrócenie właściwego znaczenia humanizmowi}

Współczesny humanizm stał się symbolem wykluczenia z przestrzeni społecznej integralnego ujęcia osoby ludzkiej, a ze swej istoty winien on służyć jej pełnemu dobru. Stąd rodzi się potrzeba przywrócenia humanizmowi znaczenia, jakie zawiera się w jego istocie. Takie zadanie wyznaczył Jan Paweł II, pisząc o powinnościach rodziny chrześcijańskiej we współczesnym świecie:

Przed całym Kościołem staje zadanie głębokiego przemyślenia i zaangażowania, by nowa kultura, która się rodzi, została na wskroś przeniknięta Ewangelią, by uznane zostały prawdziwe wartości, by bronione były prawa mężczyzny i kobiety i szerzona sprawiedliwość wewnątrz samych struktur społecznych. W ten sposób „nowy humanizm” nie będzie odciągał ludzi od Boga, lecz bardziej do Niego zbliżał ${ }^{71}$.

Cel ten może zostać osiągnięty poprzez działania edukacyjne, zmierzające do uświadomienia współczesnemu człowiekowi godności osobowej. Wydaje się, że w czasach, gdy godność ta jest deprecjonowana, istnieje duże zapotrzebowanie społeczne na przypominanie o godności człowieka i troskę o jej rozwój. Integralne wychowanie, w którym nie brak odwołania i rzeczywistego poszanowania godności każdego człowieka, jest drogą do kreowania „nowego humanizmu”, adekwatnego do nowej kultury, o której pisał papież.

$7^{\circ}$ A. Rynio, Wychowanie integralne..., dz. cyt., s. 411.

${ }^{71}$ Jan Paweł II, adhort. apost. Familiaris consortio do biskupów, kapłanów i wiernych całego Kościoła Katolickiego o zadaniach rodziny chrześcijańskiej w świecie współczesnym, 22.11.1981, Wrocław 2000, nr 8. 


\section{Przywrócenie sacrum do przestrzeni życia społecznego}

Zadanie to wydaje się trudne ze względu na wzrastającą w społeczeństwie niechęć do tego, co jest związane z religią. Jednak próby przywrócenia znaczenia sacrum nie muszą odbywać się tylko w przestrzeni polemiki społecznej. Może ona zostać wsparta poprzez świadectwo ludzi wierzących w Chrystusa, dla których obecność znaków i symboli religijnych jest ważną potrzebą, stąd dążą do znalezienia dla nich miejsca w domach, miejscach pracy czy odpoczynku. Wydaje się, że ważne jest także świadectwo osób duchownych i konsekrowanych, które przez noszenie stroju duchownego przypominają o transcendentnym sensie ludzkiego życia. Świadectwo to jest szczególnie istotne także podczas katechezy szkolnej, która jest miejscem kształtowania postaw społecznych.

\section{Promocja pozytywnych postaw i zjawisk}

Promowanie postaw, które stanowią odzwierciedlenie idei osoby w jej integralnym ujęciu, wydaje się szczególnie istotne ze względu na fakt, że współczesny Polak coraz częściej domaga się obecności pozytywnego języka w przestrzeni społecznej. Stawia to zadanie promowania tego, co pozytywne w integralnej wizji człowieka, i pokazywania pozytywnych przykładów, w miejsce przesadnego moralizowania, o czym przypomina papież Franciszek ${ }^{72}$. Skuteczną metodą tej promocji może być dowartościowanie znaczenia mass mediów chrześcijańskich oraz tych, których celem jest promowanie prawdziwego dobra. Użyteczne może być także popieranie inicjatyw społecznych mających na celu promowanie w kulturze wartości i ukazywanie wzorców wychowawczych ${ }^{73}$.

\section{Współtworzenie edukacji}

Promocja integralnej wizji człowieka wymaga współdziałania wielu osób i instytucji. Ważną rolę pośród nich pełni szkoła. Istotne jest, by treści przekazywane w szkole byly promocją osoby, a programy nauczania były skoncentrowane na szeroko pojętym dobru ucznia, uwzględniającym jego integralny rozwój. Do tego potrzebna jest wola dialogu i uwzględnienia współpodmiotowości szkoły, rodziny i Kościoła.

${ }^{72}$ Por. Franciszek, Przemówienie Ojca świętego Franciszka przed modlitwa „Regina caeli”, 19.04.2015, http://info.wiara.pl/doc/2440614.Swiadectwo-to-nie-teoria-ani-moralizowanie, 21.10.2016.

${ }^{73}$ Przykładem może być produkcja filmów Karolina (reż. D. Regucki, Polska 2014) i Bóg w Krakowie (reż. D. Regucki, Polska 2016) zrealizowana przez Stowarzyszenie Rafael: www. stowarzyszenierafael.pl, 21.10.2016. 
W polskiej rzeczywistości edukacyjnej coraz ważniejszą rolę pełnią szkoły katolickie, które mają szczególne zadanie wyznaczone przez świętego papieża: „Czerpiąc z bogactwa swoich tradycji pedagogicznych, macie odważnie poszukiwać właściwych odpowiedzi na wyzwania, jakie niosą z sobą nowe style myślenia i postępowania dzisiejszej młodzieży, aby dzięki temu szkoła katolicka była środowiskiem wychowania integralnego, które kieruje się jasnym programem wychowawczym i ma fundament w Chrystusie" 74 .

Realizacja tego przesłania jest ważna także z tego względu, że szkoły katolickie kształcą dzieci nie tylko z rodzin silnie zaangażowanych religijnie, ale także mających luźniejszy związek z wiarą, przez co stwarzają okazję do nowej ewangelizacji.

\section{Zakończenie}

Personalistyczna koncepcja osoby i jej zredukowane ujęcie stanowią przeciwieństwa, które koegzystują w kulturze i w jej szczególnym obszarze, jakim jest wychowanie. Odmienne założenia powodują, że każda z tych koncepcji promuje właściwe sobie wartości i obie traktują siebie wzajemnie jako błędne. Rodzi się więc pytanie o niezawodne kryterium falsyfikacji jednej z nich. Jeśli przyjąć, że ekspansywność redukcjonistycznej wizji człowieka jest wyznacznikiem jej żywotności i prawdziwości, to z pewnością należałby przyznać rację tym, którzy propagują tę koncepcję. Jednak to kryterium nie jest zadowalające. Wydaje się, że fakt nienarzucania koncepcji integralnej wizji człowieka i towarzyszącego jej wychowania przemawia na korzyść personalizmu prezentowanego przez Jana Pawła II.

Propozycja całościowego spojrzenia na człowieka jest wymagająca i niełatwa w realizacji. Jednak zawarte $\mathrm{w}$ niej założenia są tak transparentne, że same w sobie zachęcają do spojrzenia na osobę ludzką w szerszym niż popularnie kontekście, a przez to do odkrycia głębi godności człowieka. To stwierdzenie wydaje się kluczowe w kontekście dokonanych analiz. Pozostałe wnioski i implikacje wyjaśniają i uzupełniają je.

${ }^{74}$ Jan Paweł II, Zadania szkoły katolickiej dzisiaj. Przemówienie do uczestników Międzynarodowego Kongresu Katolickich Szkół Europy, 28.04.2001, http://www.opoka.org.pl/biblioteka/W/w / jan_pawel_ii/przemowienia/szk_katolickie_28042001.html, 21.10.2016. 


\begin{abstract}
ABStrakT
Wielość filozoficznych koncepcji osoby ludzkiej powoduje, że niezbędna jest refleksja nad ich założeniami. Szczególnie ważne wydaje się zwrócenie uwagi na personalistyczną koncepcję osoby i jej zredukowane ujęcie, które promują właściwe sobie, przeciwstawne wartości. Zagadnienie integralnego i zredukowanego ujęcia osoby oraz jego kulturowego i wychowawczego znaczenia stało się zasadniczym obszarem badań podjętych na rzecz tego artykułu. Ich efektem jest zwrócenie uwagi na błąd antropologiczny tkwiący u podstaw redukcjonistycznych koncepcji osoby oraz podkreślenie znaczenia, jakiego w tym kontekście nabiera integralna wizja człowieka. Jest ona osadzona na założeniach personalizmu, do którego wielokrotnie nawiązuje Jan Paweł II. Integralna pedagogika personalistyczna wpływa pozytywnie nie tylko rozwój młodego pokolenia, ale także na kulturowy wymiar życia społecznego.
\end{abstract}

\title{
SEOWA KLUCZOWE
}

kultura, wychowanie, personalizm, integralność, redukcjonizm

\section{Abstract \\ Integral vision of man as the basis of culture and education}

There is a variety of concepts of man in philosophy. Thus, it becomes essential to reflect on their assumptions. It seems particularly important to focus on the personalist as well as on the reduced vision of man which promote contradictory values. The research conducted for the purpose of this work concentrated mainly on the integral and reduced vision of man and on their cultural and educational value. The research indicates an anthropological error which lies at the root of the reduced vision of man. It also shows the importance of the integral vision of man based on the assumptions of personalism which John Paul II frequently referred to. Integral and personalist pedagogy has a positive impact not only on the development of young generation but also on the cultural dimension of social life.

\section{KEY WORDS}

culture, education, personalism, integrity, reductionism

\section{BiBLIOGRAFIA}

Adamski F., Kultura między sacrum i profanum, [w:] Człowiek, wychowanie, kultura. Wybór tekstów, red. F. Adamski, Kraków 1993. 
Adamski F., Pedagogika chrześcijańska pedagogika personalistyczna, „Paedagogia Christiana" 31 (2013) nr 1.

Adamski F., Personalizm i pedagogika personalistyczna, [w:] Encyklopedia pedagogiczna XXI wieku, t. 4, red. T. Pilch, Warszawa 2005.

Adamski F., Posłowie, [w:] Wychowanie personalistyczne, red. F. Adamski, Kraków 2005.

Arystoteles, O duszy, oprac. P. Siwek, Warszawa 1988.

Bóg $w$ Krakowie, reż. D. Regucki, Polska 2016 (film).

Chałas K., Wychowanie w ujęciu Jana Pawła II inspiracją do budowania programu wychowawczego reformujacej się szkoty, [w:] Wychowanie ku wartościom w świetle nauczania Jana Pawła II. Elementy teorii i praktyki, t. 3, red. K. Chałas, Lublin-Kielce 2006.

Chudy W., Kłamstwo społeczne i jego skutki, [w:] Błąd antropologiczny, red. A. Maryniarczyk, K. Stępień, Lublin 2003.

Cichosz W., Koncepcja osoby ludzkiej w filozofii św. Tomasza z Akwinu, „Studia Gdańskie" 13 (2000).

Czekalski R., Personalistyczna pedagogika wychowawcza Jana Pawła II, „Warszawskie Studia Teologiczne" 21 (2008), s. 183-19o.

Czekalski R., Personalistyczne podstawy wychowania, Warszawa 2009.

Dec I., Humanizmy i ich roszczenia w wyjaśnianiu człowieka, [w:] Błąd antropologiczny, red. A. Maryniarczyk, K. Stępień, Lublin 2003.

Dziewiecki M., Pedagogika integralna, Warszawa 2010.

Dziewiecki M., Wychowanie w dobie ponowoczesności, Kielce 2002.

Franciszek, Przemówienie Ojca świętego Franciszka przed modlitwa „Regina caeli”, 19.04.2015, http://info.wiara.pl/doc/2440614.Swiadectwo-to-nie-teoria-ani-moralizowanie.

Galarowicz J., Człowiek jest osobą. Podstawy antropologii filozoficznej Karola Wojtyły, Kraków 1994.

Godawa G., Szkoła skoncentrowana na uczniu a afirmacja pajdokracji, [w:] Szkoła i jej etyczne wyzwania, red. J. Siewiora, Tarnów 2015.

Granat W., Personalizm chrześcijański, Poznań 1985.

Jaeger W., Paideia. Formowanie człowieka greckiego, tłum. M. Plezia, H. Bednarek, Warszawa 2001.

Jan Paweł II, enc. Centesimus annus do czcigodnych braci w episkopacie, do kapłanów i rodzin zakonnych, do wiernych Kościoła Katolickiego i wszystkich ludzi dobrej woli w setną rocznicę encykliki Rerum novarum, 1.05.1991, Wrocław 2000.

Jan Paweł II, adhort. apost. Familiaris consortio do biskupów, kapłanów i wiernych całego Kościoła Katolickiego o zadaniach rodziny chrześcijańskiej w świecie współczesnym, 22.11.1981, Wrocław 2000. 
Jan Paweł II, Przemówienie wygłoszone w siedzibie UnESCO, Paryż, 2.06.198o, [w:] Jan Paweł II, Wiara i kultura. Dokumenty, przemówienia, homilie, Rzym-Lublin 1988. Jan Paweł II, Zadania szkoły katolickiej dzisiaj. Przemówienie do uczestników Międzynarodowego Kongresu Katolickich Szkół Europy, 28.04.2001, http://www.opoka.org. pl/biblioteka/W/wP/jan_pawel_ii/przemowienia/szk_katolickie_28042001.html.

Kaczmarek K., Gadacz T., Racje za personalistyczna filozofia wychowania, [w:] Wychowanie personalistyczne. Wybór tekstów, red. F. Adamski, Kraków 2005.

Karolina, reż. D. Regucki, Polska 2014 (film).

Kiereś B., Personalizm jako odpowiedź na antyedukację, „Człowiek w Kulturze” 25 (2015).

Kiereś H., Błąd antropologiczny w sztuce, [w:] Błąd antropologiczny, red. A. Maryniarczyk, K. Stępień, Lublin 2003.

Krąpiec M. A., Człowiek bytem osobowym, [w:] Personalistyczna filozofia wychowania, red. F. Adamski, Kraków 1999.

Krąpiec M. A., Osoba ludzka i błędy w jej rozumieniu, [w:] Błąd antropologiczny, red. A. Maryniarczyk, K. Stępień, Lublin 2003.

Lorenc J., Wychowanie człowieka w ujęciu pedagogiki personalistycznej, „Zeszyty Naukowe Wyższej Szkoły Humanitas" 10 (2015).

Majkrzak H., Filozofia wychowania w ujęciu św. Tomasza z Akwinu, „Człowiek w Kulturze" 17 (2005).

Maryniarczyk A., Koncepcja bytu a rozumienie człowieka, [w:] Błąd antropologiczny, red. A. Maryniarczyk, K. Stępień, Lublin 2003.

Mastalski J., Zarys teorii wychowania, Kraków 2002.

Nowak M., Filozofia człowieka podstawa filozofii wychowania, [w:] Wychowanie personalistyczne, red. F. Adamski, Kraków 2005.

Parzych-Blakiewicz K., Personalistyczne podstawy humanizmu chrześcijańskiego. Zarys problematyki, „Teologia w Polsce” 5 (2011) nr 2.

Pawłowicz J. J., Implikacje moralne teologii wspólnoty małżeńsko-rodzinnej w nauczaniu Cerkwi prawosławnej i Kościoła rzymskokatolickiego. Studium porównawcze, Tuchów 2011.

Piąta pielgrzymka Jana Pawła II do Ojczyzny, oprac. J. Górny, Olsztyn 1997.

Platon, Fajdros, [w:] Platon, Dialogi, tłum. W. Witwicki, Warszawa 2007.

Rotkiewicz H., Jean-Jacques Rousseau a kategoria „innego”, „Przegląd Filozoficzny Nowa Seria" 21 (2012) nr 4.

Rubacha K., Budowanie teorii pedagogicznych, [w:] Pedagogika. Podręcznik akademicki, t. 1, red. Z. Kwieciński, B. Śliwerski, Warszawa 2008.

Rynio A., Atrakcyjność wychowania chrześcijańskiego, [w:] Wychowanie chrześcijańskie. Między tradycją a wspótczesnościa, red. A. Rynio, Lublin 2007. 
Rynio A., Wychowanie integralne w myśli Jana Pawła II, Lublin 2004.

Rynio A., Wychowanie w ujęciu Jana Pawła II. Wybrane zagadnienia teoretyczne, [w:] Wychowanie ku wartościom w świetle nauczania Jana Pawła II. Elementy teorii i praktyki, t. 3, red. K. Chałas, Lublin-Kielce 2006.

Schoenebeck H. von, Antypedagogika. Być i wspierać zamiast wychowywać, tłum.

N. Szymańska, Warszawa 2007.

Swieżawski S., Św. Tomasz na nowo odczytany, Kraków 1983.

Śliwerski B., Pedagogika ogólna. Podstawowe prawidłowości, Kraków 2012.

Św. Tomasz z Akwinu, Suma Teologiczna, t. 13, tłum. P. Bełch, Londyn 1986.

Tomasik P., Pedagogika wobec kryzysu wychowania, „Warszawskie Studia Teologiczne” 11 (1998).

Wilk J., Wychowawca wobec pytania: „Kim jest dziecko”, [w:] Oblicza dzieciństwa, red.

D. Kornas-Biela, Lublin 2001.

Włosiński M., Etyczne i pedagogiczne wartości przesłania Jana Pawła II - papieża nadziei, „Rocznik Naukowy Kujawsko-Pomorskiej Szkoły Wyższej w Bydgoszczy” 4 (2009).

Wojtyła K., Miłość i odpowiedzialność, Lublin 1986.

Wysocka M., Personalizm, „Studia nad Rodziną” 10 (2006). 